\title{
VIAJANDO CON DON QUIJOTE EN EL SIGLO XXI
}

Odilíe Rojas López ${ }^{1}$

\section{Resumen}

Don Quijote ha cabalgado con nosotros por largo tiempo y como si no fuera suficiente la lucha contra los molinos de viento, Don Quijote de la Mancha tendrá que luchar contra muchas situaciones de nuestra época actual. ¿Logrará esta hazaña el Caballero de la Triste Figura? El reto es dar la respuesta.

Por tal motivo, la autora de este ensayo traslada al Caballero de la Triste Figura y lo inserta en la sociedad del siglo XXI. Transforma los valores, costumbres y puntos de vistas de la época en que se desarrolla la obra literaria y establece una serie de correlaciones entre el texto literario, el personaje principal y las diversas situaciones cotidianas actuales. Ciertamente, Don Quijote seguirá luchando contra las situaciones de nuestra época actual. Sin duda alguna este hidalgo está aún entre nosotros.

\section{Abstract}

Don Quixote has ridden with us for a long time now, and as if his fight against windmills were not enough, Don Quixote still has many more difficult situations to combat in the present times. Will the Knight of the Sad Figure accomplish this new deed?

It is our challenge to find an answer to this inquiry. For this purpose, the author of this essay inserts the Knight of the Sad Figure in XXI century society. The author transforms the values, costumes and points of view of the times of the literary piece and establishes a series of relationships between the literary text, the main character and several current daily life situations. Don Quixote will certainly continue his fight against all the conditions we encounter nowadays. There is no doubt, then, that this knight still lives among us.

\section{Palabras claves}

Don Quijote, lucha, educación, sociedad del siglo XXI.

\footnotetext{
1 Maestra costarricense que trabaja en la Escuela La Isla y vive en Horquetas de Sarapiquí. Con este tema ganó el concurso regional ensayo, que se realizó en conmemoración del Cuarto Centenario de la aparición de la obra de Miguel de Cervantes: Don Quijote de la Mancha.
} 
in darme cuenta, toda la vida, Don Quijote ha viajado conmigo. Durante la secundaria, me sirvió de inspiración y después se quedó dentro de mí, pues cada persona, aunque no quiera aceptarlo, tiene un poco de loca, un poco de poeta y un poco de cuerda.

¿Quién no sueña con cambiar las cosas que le hacen daño, con quitar los obstáculos que no le dejan avanzar, con arrancar las malas hierbas que no permiten recoger la cosecha? Muchas veces disfrazamos la realidad para no sentir el peso de esta en nuestras espaldas, para no sentir su fuerza sobre nuestros pies cansados.

Si el soñar con imposibles, el querer cambiar la realidad, el enfrentarse a situaciones difíciles y creer poder alcanzar una estrella, es estar loco, entonces, lo acepto y lo estoy, ya que con esta forma de actuar me explico el porqué de mi existencia y me aproximo a alcanzar el objetivo de todo ser: "buscar la felicidad".

¿Cuántos molinos de viento he tenido que enfrentar? El primero, el más potente, el que dejó más huella, fue la sociedad, que no supo comportarse con una niña huérfana. El Quijote que llevo dentro se defendió con pleitos, con gritos, con llantos, pues se le acusaba de ser el culpable de todo lo que pasaba en el aula, en los recreos, en la calle, en el mundo que lo rodeaba. El que gritaba, el que empezaba los pleitos, el que andaba a la defensiva, el que acusaba a los demás.

¿Todo para qué? Si después quedaba tirado en el suelo, humillado, destrozado y sin una madre a quien recurrir. _ ¡Oh Don Quijote, cómo me identifico contigo! Sé lo que duelen las heridas hechas por el aspa de ese molino. Las cicatrices duelen aún más y aunque haya pasado el tiempo, siguen doliendo igual. Pero no podemos quedarnos tirados aquí, mi valiente caballero, debemos pararnos, seguir adelante y enfrentar las muchas que vendrán.

Como educadora, diariamente debo luchar contra el gran molino de viento llamado "Sistema Educativo". ¿Cómo pretende este gran gigante que una docente con seis grupos a cargo, en una institución con carencia de lo básico para desarrollar el programa, dé el mismo rendimiento que una, con todo lo necesario para trabajar bien? Pero la valentía de mi inseparable amigo me motiva a realizar el trabajo con lo que cuento.

¿Cómo pretende este molino que una maestra unidocente, quien dedica el horario completo a la atención de los niños y las niñas, deba entregar los mismos informes que se solicitan a los directores que están en una oficina, solamente realizando ese tipo de trabajo?

Los que están allá en las oficinas centrales, cada vez inventan más papeles que deben ser entregados por el(la) educador(a), olvidándose que el tiempo 
que dedican a estos formalismos, es valiosísimo si se hubiese invertido en la atención individual y grupal de los(as) educandos(as). Muchos de esos papeles nadie los lee. Porque no creo que todos los planes institucionales, los de prevención de desastres, los de seguridad escolar y un sinfín de informes que nos solicitan, sean leídos minuciosamente, como los elaboramos.

Debemos ser más prácticos, dedicar un porcentaje mayor de tiempo a los niños y las niñas si queremos que la formación que reciban sea la mejor. No digo que no se necesita la supervisión, claro que se necesita, pero hay que ser más concretos, más realistas y no permitir que los medios obstaculicen llegar al fin.

¿Por qué no permiten que el tiempo del(la) educador(a) sea invertido en lo que verdaderamente vale la pena?

El niño o la niña necesita nuestras manos en el momento oportuno, nuestro consejo y orientación cuando está en problemas, nuestro apoyo, consuelo y aliento cuando sufre, nuestro tiempo para compartir sus triunfos, nuestra ayuda para minimizar su dolor, nuestra sabiduría y paciencia para entender sus gritos y pleitos. Necesita nuestra vista minuciosa para identificar sus golpes, para ver caer una lágrima en su pupitre, nuestra discreción para secar esa lágrima sin que sus compañeros(as) la noten. — ¡Oh Don Quijote, con cuántos gigantes luchamos diariamente! Sin su ayuda, coraje e insistencia yo no los hubiese enfrentado. Es usted, caballero, quien me da la fuerza para querer cambiar el mundo, porque me rehúso a permitir que mis niños y niñas sufran, a aceptar que no se puede hacer nada.

Estos molinos me inspiran a buscar mi Dulcinea, ya que todo caballero andante debe tener algo que sea acicate para sus luchas, pensamiento perenne que lo guíe y a quien ofrezca sus hazañas.

Por lo tanto, ofrezco mis méritos a la formación de la niñez que pasa por mi salón de clase. Lucho para que el ambiente donde se desenvuelva cada pequeño(a) esté lleno de amor, respeto, confianza, responsabilidad, armonía, cooperación, participación, paz, tolerancia, amistad, solidaridad y todos los valores que hagan de ellos(as) niños(as) felices, autónomos(as), capaces de enfrentarse al mundo con unas bases bien sólidas. Bases que no serán movidas por los molinos de viento a los cuales tendrán que enfrentarse en el transcurso de sus vidas.

Los gigantes que atacarán a mis niños y niñas son los mismos que me atacaron; sin embargo, las armas no serán las mismas. Yo usé la fuerza, ellos(as) usarán el razonamiento; arma que hará la diferencia al final de la batalla.

Además de estos gigantes, cada día se presentarán otros más disfrazados que los primeros. Vendrán los de la prostitución, drogadicción, desintegración de los hogares, corrupción, influencia negativa de la sociedad; pero mis 
niños y niñas, con su armadura bien llevada, sabrán enfrentarse y luchar por su Dulcinea.

Todos debemos imitar al Caballero de la Triste Figura y que nuestra Dulcinea sea "Buscar la Felicidad"; para ello lo único que hay que hacer es amar y servir. Lo demás vendrá por añadidura. Dios no ha mandado a nadie a sufrir. Estamos en la obligación de buscar la felicidad a como dé lugar, sin hacer daño a nuestro prójimo, a la naturaleza, ni a nosotros mismos. Con esta ideología y armados con los valores, enfrentamos, junto con Don Quijote de la Mancha, todos los molinos de viento que se nos avecinan. 